\title{
1 An aminoacylation independent activity of PheRS/FARS \\ 2 promotes growth and proliferation
}

$5 \quad$ Manh Tin $\mathrm{Ho}^{1}$, Jiongming $\mathrm{Lu}^{2}$, Beat Suter ${ }^{1}$

7 Affiliations:

$8{ }^{1}$ Institute of Cell Biology, University of Bern, Baltzerstrasse 4, Bern 3012, Switzerland.

9 2Present address: Max Planck Institute for Biology of Ageing, 50931 Köln, Germany.

10 Corresponding author: beat.suter@izb.unibe.ch

17 Keywords: aminoacyl tRNA synthetase, non-canonical function, PheRS, FARS, cell growth

18 and proliferation 
26 Author contributions: T.H., J.L. and B.S. conceived the ideas and designed the experiments.

27 T.H. conducted most experiments and performed the analysis of the results. J.L. performed

28 the loss-of-function experiments of PheRS and the mTOR signaling tests, the adult wing

29 measurements and the FACS analysis, including analyzing their data. T.H., J.L. and B.S.

30 wrote the manuscript. 


\section{Summary / Abstract}

35 Aminoacyl-tRNA synthetases (aaRSs) not only load the appropriate amino acid onto their 36 cognate tRNA, but many of them perform additional functions that are not necessarily related

37 to their canonical activities. Phenylalanyl-tRNA synthetase (PheRS/FARS) levels are elevated

38 in various cancer cells compared to their normal cell counterparts. However, whether and how

39 these levels might contribute to tumor formation was not clear. Here, we show that PheRS is

40 required for cell growth and proliferation. Interestingly, elevated expression of the $\alpha$-PheRS

41 subunit alone stimulates cell growth and proliferation. In the wing discs system, this leads to a

42 strong increase of mitotic cells. Clonal analysis of twin spots in dividing follicle cells revealed

43 that elevated expression of the $\alpha$-PheRS subunit causes cells to grow and proliferate about $25 \%$

44 faster than their normal twin cells. Importantly, this stimulation of growth and proliferation

45 neither required the $\beta$-PheRS subunit nor the aminoacylation activity, and it did not visibly

46 stimulate translation. These results, therefore, revealed a non-canonical function of an ancient

47 housekeeping enzyme, providing novel insight into its roles in health and diseases. 


\section{Introduction}

50 Many cancer tissues display higher levels of Phenylalanyl-tRNA synthetase (PheRS, FARS, or

51 FRS) than their healthy counterparts according to the database "Gene Expression across

52 Normal and Tumor tissue" (GENT2) (Park et al., 2019). Interestingly, a correlation between tumorigenic events and PheRS expression levels had been noted already much earlier for the development of myeloid leukemia (Sen et al., 1997) and this was further supported by additional results from the Safro group (Rodova et al., 1999). Despite this, a possible causative connection between elevated PheRS levels and tumor formation had so far not been reported and, to our knowledge, also not been studied. This might have been due to the assumption that higher PheRS levels could simply reflect the demand of tumorigenic cells for higher levels of translation, or it could have to do with the difficulty of studying the moonlighting function of a protein that is essential in every cell for basic cellular functions such as translation. RNAs (tRNAs) with their cognate amino acid, a process called aminoacylation which serves as a key step for protein translation. This activity makes them essential for the accurate translation of the genetic information into polypeptide chains (Schimmel and Soll, 1979). Besides their canonical role in translation, an increasing number of aaRSs have been shown to perform additional functions in the cytoplasm, the nucleus, or even outside of the cell (CasasTinto et al., 2015; Gomard-Mennesson et al., 2007; Greenberg et al., 2008; Guo and Schimmel, 2013; Lee et al., 2004; Nathanson and Deutscher, 2000; Otani et al., 2002; Smirnova et al., 2012; Zhou et al., 2014). For example, the amino-acid binding site of LysRS has an immune response activity; or TrpRS inhibits the vascular endothelial (VE)-cadherin and through this elicits an anti-angiogenesis activity (Tzima et al., 2005; Yannay-Cohen et al., 2009). 
73 ( $\beta$ ) subunits responsible for charging tRNA ${ }^{\text {Phe }}$ with phenylalanine is one of the most complex

74 members of the aaRSs family (Roy and Ibba, 2006). The $\alpha$ subunit includes the catalytic core of the tRNA synthetase and the $\beta$ subunit contains structural modules with a wide range of

76 functions, including tRNA anticodon binding, hydrolyzing mis-activated amino acids, and editing wrongfully aminoacylated tRNA ${ }^{\text {Phe }}$ species (Ling et al., 2007; Lu et al., 2014; Roy and Ibba, 2006). Importantly, both subunits are required for the aminoacylation of tRNA ${ }^{\text {Phe }}$.

We set out to address the question of whether and how elevated levels of PheRS can contribute to over-proliferation. To test for this activity, we studied the role of PheRS levels in the Drosophila model system with the goal of finding out whether elevated levels of PheRS allow higher translation activity or whether a moonlighting role of PheRS might provide an activity that might contribute to elevated growth and proliferation. We found that $\alpha$-PheRS

84 levels regulate cell growth and proliferation in different tissues and cell types. Interestingly, 85 elevated levels of $\alpha$-PheRS do not simply allow higher levels of translation. Instead, $\alpha$-PheRS 86 performs a moonlighting function by promoting growth and proliferation independent of the $\beta$-PheRS subunit and even if it lacks the aminoacylation activity. 


\section{Results}

\section{PheRS is required for growth and proliferation}

91 The Drosophila FARSA and FARSB homologs $\alpha$-PheRS and $\beta$-PheRS are essential genes contribute to growth, we tested whether reduced levels in specific tissues affect the growth of the organ and animal. For this, we used RNAi to reduce their activity in two specific tissues, the eye, an organ that is not essential for viability, and the fat body (Fig 1A,B). Indeed, knocking down either of the two subunits in the developing eye dramatically reduced the size of the adult eye (Fig 1A). Similarly, reducing $\alpha$-PheRS or $\beta$-PheRS expression levels in the larval fat body also caused a growth reduction. However, presumably because of its role in systemic growth (Texada et al., 2020), the fat body knockdown of PheRS reduced the size of the entire pupae (Fig 1B).

To further analyze the changes at the cellular level, the effect of knocking down $\alpha$ -

PheRS and $\beta$-PheRS in Drosophila Kc cells was first examined at the level of cell proliferation

(Fig 1C). The knockdowns were carried out by adding dsRNA into the medium, and the cell numbers were recorded during the following days. Compared to the controls, cells treated with $\beta$-PheRS RNAi started to show lower cell numbers on day 3, and the cell count was around $75 \%$ of the control on day 5 . In Kc cells, knocking down either subunit alone reduces levels of the $\alpha$ - and the $\beta$-PheRS subunit ( $\mathrm{Lu}$ et al., 2014). It was therefore reassuring that $\alpha$-PheRS knockdown showed similar results. The lower number was not due to cell death, as judged by trypan blue staining of the cells before counting. No obvious increase in dead cells was detected upon RNAi treatment. As a positive control, xpd RNAi was performed and showed the

111 published increased in cell proliferation (Chen et al., 2003b). The fact that knockdown of xpd 
112 can speed up cell growth and proliferation not only indicates that the Kc cells were healthy, but

113 also that the PheRS levels are not limiting for growth and proliferation, but can sustain even

114 higher proliferative activity.

Determining the mitotic index upon PheRS knockdown revealed that the reduced

116 PheRS levels caused a strong reduction of mitotic cells as indicated by the lower fraction of

117 phospho-Histone 3 (PH3; mitotic marker) positive cells. The RNAi treatment reduced the

118 mitotic index to $1.7 \% \pm 0.16$, which corresponded to half of the control $(3.3 \% \pm 0.16)$ (Fig.

119 1D). Similarly, cell size was also affected by PheRS knockdown (Fig 1E). The cell size showed

120 a reduction that was similar to the one observed upon RNAi-mediated knockdown of raptor, a

121 component of the TORC1 signaling that regulates cell growth (Kim et al., 2002). These experiments showed that $\alpha$-PheRS and $\beta$-PheRS are required for normal growth and the enzymatic activity of PheRS in charging the tRNA ${ }^{\text {Phe }}$ with its cognate amino acid

125 phenylalanine, or it might point to a novel, possibly moonlighting function of PheRS in 126 stimulating growth and proliferation.

\section{PheRS lacks apparent amino acid sensor activity for TORC1}

129 The TORC1 signaling pathway activates growth and proliferation of cells depending on the

130 availability of amino acids, growth factors, and energy (Laplante and Sabatini, 2012;

131 Wullschleger et al., 2006). In addition to its canonical function in charging tRNA ${ }^{\text {Leu }}$ with

132 leucine, the LeuRS serves as the central amino acid sensor in this pathway (Bonfils et al., 133 2012b; Han et al., 2012b). We, therefore, tested whether PheRS might also be involved in 134 nutrient sensing for TORC1 signaling in an analogous way. Amino acid deprivation causes 135 downregulation of phosphorylation of dS6K in Kc cells, and subsequent stimulation with 
amino acids restores phospho-dS6K levels (Kim et al., 2008). The Rag complex was identified

137 as a nutrient sensor in this pathway, and knockdown of $\operatorname{Rag} A$ prevents the TORC1 complex

138 from sensing the availability of amino acids (Kim et al., 2008; Sancak et al., 2008). We,

139 therefore, used $\operatorname{Rag} A$ as our control (Fig 2A,B). In contrast to $\operatorname{Rag} A$, knocking down $\beta$-PheRS

140 (which also reduces $\alpha$-PheRS levels) did not prevent amino acids sensing in this assay and

141 phosphorylation of dS6K was still induced to a similar level as in the control when amino acids

142 or phenylalanine were re-added after deprivation (Fig 2A,B). In this case, it did not matter

143 whether we added back all amino acids or only L-Phe. Although we cannot rule out that the

144 RNAi knockdown was insufficient to reveal an amino acid-sensing function for PheRS, the

145 results seem to suggest that PheRS might not serve as an aa sensor upstream of the TORC1

146 complex.

\section{$\alpha$-PheRS activity is sufficient to induce additional M-phase cells}

149 Circumstantial evidence suggests that elevated PheRS levels do not simply allow a higher

150 translational activity to overcome a growth rate restriction imposed by hypothetically limiting

151 levels of PheRS. PheRS is unlikely to be rate-limiting for cellular growth because animals with only one copy of $\alpha$-PheRS ( $\alpha$-PheRS/-) or $\beta$-PheRS ( $\beta$-PheRS/-) do not show a phenotype (Lu

et al., 2014). Furthermore, Kc tissue culture cells can be stimulated to grow more rapidly

154 without artificially over-expressing $\alpha$-PheRS or $\beta$-PheRS (Fig 1C; (Chen et al., 2003a). To test

155 whether elevated levels of PheRS can stimulate growth or proliferation, we expressed $\alpha$ -

156 PheRS, $\beta$-PheRS, and both subunits together in the posterior compartment $(\mathrm{P})$ of wing discs

157 using a Gal4 driver under the control of the engrailed (en) promoter. This en-Gal4 transcription

158 factor drives the expression of the $\alpha$-PheRS and $\beta$-PheRS open reading frames (ORFs) that 
160 genome that also contains the endogenous $\alpha$-PheRS and $\beta$-PheRS genes. In this assay, the

161 anterior compartment expresses normal endogenous PheRS levels and serves as an internal

162 control. The posterior compartment expresses the endogenous $\alpha$-PheRS and $\beta$-PheRS genes

163 and the two transgenes driven by en-Gal4. When $\alpha$-PheRS and $\beta$-PheRS levels were raised in

164 the posterior wing disc compartment together, the PH3 labeling revealed a $40 \%$ increase in

165 mitotic cells in the posterior $(\mathrm{P})$ compartment relative to the anterior $(\mathrm{A})$ one of the same wing 166 disc (Fig 3D). Surprisingly, the same result was obtained when only the levels of the $\alpha$-PheRS

167 subunit alone were raised (Fig 3A-D), but not when only the $\beta$-PheRS subunit levels were

168 raised (Fig 3D). In addition, raising the $\alpha$-PheRS subunit levels alone did not affect the $\beta$ -

169 PheRS subunit levels (Fig 3C-C"'). These results pointed to the possibility that this cell cycle

170 effect might not only depend on the $\alpha$-PheRS subunit alone but that it might also be a translation

171 independent function of $\alpha$-PheRS because aminoacylation requires both PheRS subunits to

172 ligate Phe to the tRNA ${ }^{\text {Phe }}$ (Lu et al., 2014; Mosyak et al., 1995); Fig 4A). The fact that elevated

$173 \alpha$-PheRS levels alone are sufficient to raise the mitotic index is therefore another strong

174 indication that $\alpha$-PheRS possesses a proliferative activity that is unlikely to be mediated by

175 increased tRNA ${ }^{\text {Phe }}$ aminoacylation.

177 A non-canonical $\alpha$-PheRS activity induces additional M-phase cells

178 To test directly whether $\alpha$-PheRS can increase proliferation without stimulating 179 translation, we made a mutant version of $\alpha$-PheRS in which Tyr412 and Phe438 are replaced 180 by cysteines (Cys). These substitutions are predicted to block the entrance into the 181 phenylalanine binding pocket, preventing binding of Phe and aminoacylation of tRNA ${ }^{\text {Phe }}$ by 182 the mutant PheRS ${ }^{\text {Cys }}$ (Finarov et al., 2010). To test whether the PheRS ${ }^{\text {Cys }}$ substitution indeed 183 reduces the aminoacylation activity of PheRS, we expressed mutant and wild-type $\alpha$-PheRS 
184 subunits individually or together with $\beta$-PheRS subunits in E. coli, His tag-purified them and

185 performed aminoacylation assays with the same amounts of recombinant soluble proteins that

186 were normalized to BSA standards (Fig 4B). The clear band in Fig 4B showed that the Cys

187 mutation did not affect the solubility of the recombinant proteins. $\alpha$-PheRS ${ }^{\text {Cys }}$ together with

188 wild-type $\beta$-PheRS produced the same background signal as the $\alpha$-PheRS subunit alone, and

189 this background signal was only around $1 \%$ of the signal obtained with wild-type $\alpha$-PheRS plus

$190 \quad \beta$-PheRS (Fig 4A). The Drosophila gene encoding the cytoplasmic $\alpha$-PheRS subunit is located

on the X chromosome. A P-element insertion into the 5'-untranslated region of the $\alpha$-PheRS

transcript $\left(\alpha-P h e R S^{G 2060}\right)$ causes recessive lethality that can be rescued by a genomic copy of

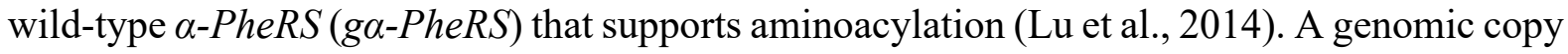
of the aminoacylation defective $\alpha-P h e R S^{C y s}, g \alpha-P h e R S^{C y s}$, did not rescue the lethality of the $\alpha$ PheRS ${ }^{G 2060}$ mutant, indicating that the Cys mutant is indeed not functional in aminoacylation in vivo in Drosophila. Despite this apparent lack of aminoacylation activity, expressing a transgenic copy of $\alpha-P h e R S^{C y s}$ (cDNA under UAS control) in the posterior compartment of the wing disc with the en-Gal4 driver caused a $67 \%$ increase in the number of mitotic cells in the above assay (Fig 3D). The fact that the mutant $\alpha-P h e R S^{C y s}$ version caused an increase in mitotic cells at least as strong as the wild-type $\alpha$-PheRS expressed in the same way, together with the fact that $\beta$-PheRS overexpression was not needed for this effect, strongly suggests that the increased mitotic index is promoted without increasing the canonical function of PheRS.

We also tested directly whether elevated expression of wild-type $\alpha$-PheRS and expression of $\alpha$-PheRS and $\beta$-PheRS together are indeed unable to cause elevated translation as we expected. For this, we analyzed protein synthesis activity in the two wing compartments by puromycin (PMY) staining using the ribopuromycylation method (RPM) (Deliu et al., 207 2017). Testing this method, we first expressed elevated levels of the transcription factor dMyc in the posterior wing disc compartment. This positive control led to an increased protein 
synthesis activity and anti-PMY signal in the dMyc over-expressing posterior compartment

210 relative to the anterior compartment of the same discs. In contrast, neither en-Gal4 driven

211 expression of $\alpha$-PheRS alone nor combined expression with $\beta$-PheRS increased the puromycin

212 labeling in the posterior compartment (Fig 3E-F', G). The combined results therefore

213 demonstrate unambiguously that elevated $\alpha$-PheRS levels cause additional cells to be in mitosis

214 through a non-canonical mechanism that does not involve a general increase in translation.

The non-canonical activity emanating from $\alpha$-PheRS or $\alpha$-PheRS ${ }^{\text {Cys }}$ is capable of

216 inducing more cells to be in mitosis. Such a phenotype could come about by specifically

217 slowing down progression through M-phase, causing higher numbers of cells to remain in the

218 PH3-positive state. Alternatively, the activity might either promote the proliferation of mitotic

219 cells or induce proliferation in non-cycling cells.

$\alpha-P h e R S$ levels accelerate growth and proliferation

222 To find out whether the cell cycle effect of elevated PheRS levels is a more general effect and

223 to test the effect of PheRS levels on growth and proliferation directly, we set up "mosaic

224 analysis with repressible cell marker" (MARCM; (Wu and Luo, 2006) assays in the ovarian

225 follicle cells. Twin-spot clones were generated with one clone expressing elevated levels of

226 PheRS and the GFP marker, and its twin clone expressing normal endogenous levels of PheRS

227 and serving as an internal control (Fig 5A). The results of this experiment showed also in the

228 follicle cells the PheRS levels affect the cell cycle because clonally elevated levels of both

229 subunits of PheRS accelerated cell proliferation on average by $32 \%$ (Fig 5B). In contrast,

230 increased expression of GFP with only the $\beta$-PheRS subunit or with GlyRS (also named

231 GARS) did not significantly promote clonal expansion (Fig 5B). This shows that the

232 stimulation of proliferation is specific for PheRS and not a general role of aaRSs. Interestingly, 
233 elevated expression of GFP with the $\alpha$-PheRS subunit alone also stimulated cell proliferation

234 autonomously by $30 \%$ (Fig 5B) and, intriguingly, this was very close to the $32 \%$ increase

235 calculated for the clone overexpressing both PheRS subunits (Fig 5B). Remarkably, the higher

236 number of mitotic cells observed upon $\alpha$-PheRS overexpression in the posterior compartment

237 of the larval wing discs (Fig 3C) was in a comparable range as the proliferation increase in the

238 follicle cell assay (Fig 5B). These results, therefore, suggest that $\alpha$-PheRS levels promote cell

239 proliferation and that $\alpha$-PheRS levels have this activity in different tissues.

We also measured the clone size of the twin spots to find out whether the elevated $\alpha$ -

241 PheRS could also enhance cell growth. Relative to the control twin spot, clonally elevated

242 levels of both subunits of PheRS and $\alpha$-PheRS subunits alone, respectively, augmented clone size by $139 \%$ and $102 \%$, respectively. In contrast, elevated levels of single $\beta$-PheRS subunits or GlyRS did not show a significant increase in clone size (Fig 5C). We also observed that the size of single cells in twin spot clones remained unchanged (Fig 5D), indicating that cell size control was not affected and that cells overexpressing $\alpha$-PheRS subunits also grow faster to sustain the higher proliferation. These results, therefore, show that $\alpha$-PheRS levels promote cell growth and proliferation and they also suggest that $\alpha$-PheRS levels have this activity in different

249 tissues. stimulated cell proliferation in the follicle cell twin spot experiment by $28 \%$ and $25 \%$, respectively (Fig 5B,C). Additionally, the clonal sizes also increased by $99 \%$ and $86 \%$, respectively (Fig 5C). These observations confirmed that in addition to the proliferative activity, the stimulation of cell growth does also not depend on increased canonical PheRS activity. 


\section{Discussion}

Our work revealed that PheRS not only charges tRNAs with their cognate amino acid

Phe but that it also performs a moonlighting function in stimulating cellular growth and proliferation. Because levels of $\alpha$-PheRS are elevated in many tumor cells compared to their healthy counterparts (Park et al., 2019) and because a positive correlation between these levels and tumorigenic events had been noted some time ago (Sen et al., 1997), it was important to find out whether elevated PheRS levels are a mere consequence of the high metabolic activity of the tumor cells or whether they might also contribute to the over-proliferation of tumor cells. Here we now showed that $\alpha$-PheRS has the potential to promote growth and proliferation and that it can do this independent of its aminoacylation activity, i.e. through a non-canonical or moonlighting activity. We found unambiguous evidence for the non-canonical nature of this proliferative activity and also showed that general translation is not elevated when this phenotype is induced by elevated $\alpha$-PheRS or even the entire PheRS protein (Fig 3D-D”). Aminoacylation of $\mathrm{tRNA}^{\text {Phe }}$ requires both subunits to form the tetrameric protein $\alpha_{2} \beta_{2}$-PheRS that can aminoacylate tRNA ${ }^{\text {Phe }}$ (Mosyak et al., 1995; Fig 4), and overexpression of an aminoacylation-dead $\alpha-P h e R S^{C y s}$ mutant subunit alone, (without simultaneous overexpression of the $\beta$-PheRS subunit) increased the cell numbers in the follicle cell clones as much as the wild-type gene did when expressed in the same way (Fig 4, 5B). The described non-canonical functions of $\alpha$-PheRS are not only independent of the aminoacylation activity, they also do not reflect a function in sensing the availability of its enzymatic substrate, Phe, for the major growth controller, the TOR kinase (Fig 2). Such activities have been described for other et al., 2012a). 
281 independently of the $\beta$-subunit (Fig 3C-C"') was surprising because previous results showed

282 that the two subunits were dependent on the presence of the other subunit for their stability

283 (Antonellis et al., 2018; Lu et al., 2014; Xu et al., 2018). Our results now show that this requirement does not apply to all cell types. In mitotically active follicle cells, the posterior compartment of the wing disc and possibly other cells, elevated expression of the $\alpha$-PheRS subunit alone produced a strong cell cycle phenotype. This suggests that the $\alpha$ - and $\beta$-PheRS subunits function together in every cell to aminoacylate tRNA ${ }^{\text {Phe }}$, but in addition, the $\alpha$-subunit can be stable in specific cell types that appear to have retained their mitotic potential. In these cells, $\alpha$-PheRS assumes a novel function in promoting cell growth and proliferation. This would then suggest that many differentiating cell types start to put a system in place that prevents $\alpha$-PheRS accumulation at high levels. Such a mechanism could then contribute to reducing the proliferative activity of differentiated cells. instance, MetRS/MRS is capable of stimulating rRNA synthesis (Ko et al., 2000), GlnRS/QRS can block the kinase activity of apoptosis signal-regulating kinase 1 (ASK1) (Ko et al., 2001) and a proteolytically processed form of YARS/TyrRS acts as a cytokine (Casas-Tinto et al., 2015; Greenberg et al., 2008). aaRSs are, however, also not the only protein family which evolved to carry out more than one function. In recent years, it has become increasingly evident

300 that many, if not most, proteins have evolved to carry out not only one, but two or more

301 functions, providing interesting challenges to figure out, which of their activities are important

302 for the specific function of a gene (Dolde et al., 2014). 
304 till now the mechanisms behind this effect remained unknown. Elevated mRNA levels of the

305 human $\alpha$-PheRS, FARSA, during the development of myeloid leukemia correlate with

306 tumorigenic events and many malignant cell lines express elevated levels of mRNA encoding

307 the PheRS subunits compared to normal human tissue (Sen et al., 1997; Rodova et al., 1999).

308 The GENT2 database published in 2019 describes also strong positive correlations between

309 PheRS subunit mRNA levels and tumorigenic events in several tissues and cancers (Barker et

310 al., 2009; Park et al., 2019). Interestingly, and consistent with our results, not all tumors that

311 displayed elevated PheRS levels showed elevated levels of $\alpha$ - and $\beta$-PheRS mRNA. For

312 instance, brain, ovary, endometrium, and bladder tumors displayed only elevated $\alpha$-PheRS

313 mRNA levels while colon, breast, lung, and liver tumors showed elevated levels of mRNAs

314 for both subunits. Because elevated levels of $\alpha$-PheRS or $\alpha-P h e R S^{C y s}$ alone can elicit mitotic

315 activity, growth, and proliferation, our results suggest that the excessive PheRS (FARS) levels

316 in tumor tissues might be able to produce such proliferative signals independent of whether

317 they also produce elevated levels of $\beta$-PheRS. Modeling the effect of elevated $\alpha$-PheRS levels

318 in Drosophila, we found that elevated levels support growth and proliferation and lead to an

319 increase in mitotic cells in different cell types. In follicle cells, more cells were produced in

320 clones expressing more $\alpha$-PheRS compared to wild-type clones. In wing discs, more mitotic

321 cells were detected in most areas with higher levels of $\alpha$-PheRS. This indicates that elevated $\alpha$-PheRS levels can indeed be a risk factor for tumor formation in several different tissues. 


\section{Materials and Methods}

325 Table 1: Key Resources Table

\begin{tabular}{|c|c|c|c|}
\hline Reagent or Resource & Sources & Identifier & $\begin{array}{l}\text { Additional } \\
\text { information }\end{array}$ \\
\hline \multicolumn{4}{|l|}{ Antibodies } \\
\hline $\begin{array}{l}\text { Anti phospho-Histone H3- } \\
\text { rabbit }\end{array}$ & Cell signaling & $9701 S$ & $1: 200 \mathrm{v} / \mathrm{v}$ \\
\hline $\begin{array}{l}\text { Anti phospho-Histone H3- } \\
\text { mouse }\end{array}$ & Cell signaling & 9706S & $1: 200 \mathrm{v} / \mathrm{v}$ \\
\hline Anti a-PheRS & Genescript & 4668 & $\begin{array}{l}\text { Customized } \\
\text { product }(1: 200 \\
\text { v/v) }\end{array}$ \\
\hline Anti $a-P h e R S$ & Genescript & 4669 & $\begin{array}{l}\text { Customized } \\
\text { product }(1: 200 \\
\text { v/v) }\end{array}$ \\
\hline Anti Myc-mouse & $\begin{array}{l}\text { Developmental } \\
\text { Studies } \\
\text { Hybridoma Bank } \\
\text { (DSHB) }\end{array}$ & 9E10 & $\begin{array}{l}\text { Supernatant }(1: 3 \\
\mathrm{v} / \mathrm{v})\end{array}$ \\
\hline Anti Puromycin & DSHB & PMY-2A4 & $1: 100 \mathrm{v} / \mathrm{v}$ \\
\hline Anti Cy3 rabbit & $\begin{array}{l}\text { Jackson Immuno } \\
\text { Research }\end{array}$ & $115-165-146$ & $1: 200 \mathrm{v} / \mathrm{v}$ \\
\hline Anti-rabbit Alexa Flour 488 & Molecular Probes & $A-11008$ & $1: 200 \mathrm{v} / \mathrm{v}$ \\
\hline Anti-rabbit Alexa Flour 488 & Molecular Probes & A-11034 & $1: 200 \mathrm{v} / \mathrm{v}$ \\
\hline $\begin{array}{l}\text { Anti-mouse Alexa Flour } \\
488\end{array}$ & Molecular Probes & A-11029 & $1: 200 \mathrm{v} / \mathrm{v}$ \\
\hline Anti-rabbit Alexa Flour 488 & Life technology & A-21206 & $1: 200 \mathrm{v} / \mathrm{v}$ \\
\hline Anti-rabbit Alexa Flour 594 & Invitrogen & $A-11037$ & $1: 200 \mathrm{v} / \mathrm{v}$ \\
\hline $\begin{array}{l}\text { Anti-mouse Alexa Flour } \\
594\end{array}$ & Molecular Probes & A-11032 & $1: 200 \mathrm{v} / \mathrm{v}$ \\
\hline $\begin{array}{l}\text { Anti-mouse Alexa Flour } \\
568\end{array}$ & Life technology & A-10037 & $1: 200 \mathrm{v} / \mathrm{v}$ \\
\hline Anti actin & Abcam & Ab18251 & $1: 1,000 \mathrm{v} / \mathrm{v}$ \\
\hline Anti GFP & ImmunoKontact & 042704 & $1: 1,000 \mathrm{v} / \mathrm{v}$ \\
\hline Anti Myc-rabbit & Santa Cruz & Sc-789 & $\begin{array}{l}\text { A-12 }(1: 1,000 \\
v / v)\end{array}$ \\
\hline $\begin{array}{l}\text { HRP Anti rabbit IgG } \\
\text { antibody (Peroxidase) }\end{array}$ & Vector & $\mathrm{Pl}-1000$ & $1: 10,000 \mathrm{v} / \mathrm{v}$ \\
\hline $\begin{array}{l}\text { HRP Anti rabbit IgG } \\
\text { antibody (Peroxidase) }\end{array}$ & Vector & PI-2000 & $1: 10,000 \mathrm{v} / \mathrm{v}$ \\
\hline
\end{tabular}




\begin{tabular}{|c|c|c|c|}
\hline Fly stocks and genetics & & & \\
\hline a-PheRSG2060/FM6 & $\begin{array}{l}\text { Bloomington } \\
\text { Drosophila Stock } \\
\text { Center (BDSC) }\end{array}$ & 26625 & \\
\hline RNAi- a-PheRS & $\begin{array}{l}\text { Vienna } \\
\text { Drosophila RNAi } \\
\text { Center (VDRC) }\end{array}$ & 33514 & \\
\hline $\begin{array}{l}\text { RNAi- } \beta \text {-PheRS } \\
\text { ga-PheRSCys } \\
\text { UAS- } a-P h e R S^{C y s}\end{array}$ & VDRC & 42046 & $\begin{array}{l}\text { Transgenic } \\
\text { construct } \\
\text { Transgenic } \\
\text { construct }\end{array}$ \\
\hline $\begin{array}{l}\text { hspFLP ; Act-Gal4/CyO ; } \\
\text { neoFRT82B,tub- } \\
\text { Gal80/TM3,Sb } \\
w \text {; If/CyO; } \\
\text { neoFRT82B,UAS- } a- \\
\text { PheRS(Cys) }\end{array}$ & & & \\
\hline eyeless-Gal4 & BDSC & 5535 & \\
\hline ppl-Gal4 & BDSC & 58768 & \\
\hline engrailed-Gal4 & BDSC & 30564 & \\
\hline UAS-GFP & BDSC & 6658 & \\
\hline$w ;$ UAS-Myc::MYC & BDSC & 9674 & \\
\hline $\begin{array}{l}\text { hspFLP/y ; + ; UAS- } \\
\text { Myc::MYC }\end{array}$ & BDSC & 9675 & \\
\hline neoFRT82B Sb1/TM6 & BDSC & 2051 & \\
\hline tub-Gal4/TM3,Sb & BDSC & 5138 & \\
\hline $\begin{array}{l}\text { y w att2A[vas- } \phi] ;+; \text { attP- } \\
86 F \\
y w ; U A S-c y t o-g a r s- \\
\text { myc/CyO }\end{array}$ & ETH Zurich & & $\begin{array}{l}\text { A gift from Hugo } \\
\text { Stocker, ETH } \\
\text { A gift from } \\
\text { Albena } \\
\text { Jordanova, VIB-U } \\
\text { Antwerp Center } \\
\text { for Molecular } \\
\text { Neurology }\end{array}$ \\
\hline
\end{tabular}

\section{Bacteria strains and vectors}

\section{XL1 blue}

Rosseta - Novagen

pET-28a - Novagen

pET LIC (2A-T)

pUASattB

\section{Agilent}

Merckmilipore

Merckmilipore

Addgene

Drosophila

Genomics

Resource Center

\section{9}

70954

69864

29665

1419
Transgenic

Transgenic construct
A gift from Hugo

A gift from

Albena

Antwerp Center

Neurology 


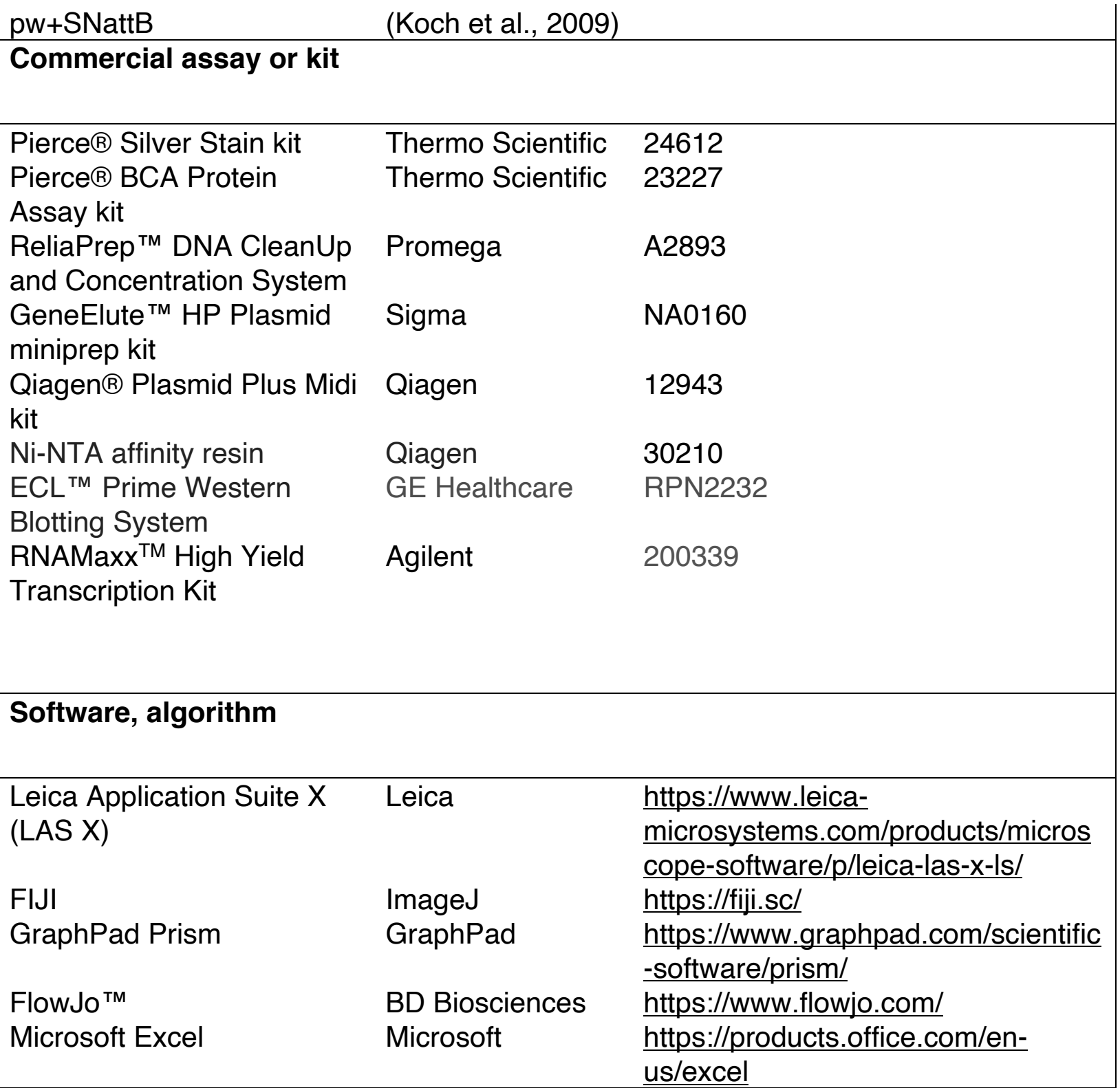

\begin{tabular}{|l|l|}
\hline \multicolumn{2}{|l|}{ Buffers } \\
\hline Lysis buffer for Drosophila tissue & Lysis buffer for bacteria \\
\hline $20 \mathrm{mM}$ Tris $\mathrm{HCl} \mathrm{pH7.4}$ & $20 \mathrm{mM}$ Tris HCl pH7.4 \\
$150 \mathrm{MM} \mathrm{NaCl}$ & $150 \mathrm{uM} \mathrm{NaCl}$ \\
$2 \mathrm{mM} \mathrm{EDTA}$ & $2 \mathrm{mM} \mathrm{EDTA}$ \\
$50 \mathrm{mM} \mathrm{NaF}$ & $50 \mathrm{mM} \mathrm{NaF}$ \\
$10 \%$ Glycerol & $10 \%$ Glycerol \\
$1 \%$ Triton X100 & $1 \%$ Triton X100 \\
1 Protease inhibitor cocktail tablet & $4 \mathrm{mM}$ Imidazole 1M \\
(Roche-4693159001) & $0.6 \%$ Lysozyme \\
1 mM phenylmethylsulphonyl fluoride & 1 Protease inhibitor cocktail tablet \\
& 1 mM phenylmethylsulphonyl fluoride \\
\hline 4\% PFA & 1X PBST \\
\hline
\end{tabular}




\begin{tabular}{|c|c|}
\hline $\begin{array}{l}\text { 1X PBST } \\
4 \%(w / v) \text { Paraformaldehyde }\end{array}$ & $\begin{array}{l}0.2 \%(\mathrm{v} / \mathrm{v}) \text { Tween } 20 \\
1 \text { X PBS }\end{array}$ \\
\hline Blocking buffer & Fly food recipe \\
\hline $\begin{array}{l}5 \%(w / v) \text { non-fat dry milk } \\
0.1 \%(v / v) \text { Triton X100 }\end{array}$ & \multirow{3}{*}{$\begin{array}{ll}20.4 \mathrm{I} & \mathrm{H}_{2} \mathrm{O} \\
1,680 \mathrm{~g} & \text { Maize flour } \\
720 \mathrm{~g} & \text { Yeast } \\
1,800 \mathrm{~g} & \text { Syrup } \\
192 \mathrm{~g} & \text { Potassium sodium tartrate } \\
\text { tetrahydrate } \\
36 \mathrm{~g} & \text { Nipagin } \\
120 \mathrm{ml} & \text { Propionic acid } \\
\end{array}$} \\
\hline 10X PBS pH 7.4 & \\
\hline $\begin{array}{l}10.6 \mathrm{mM} \mathrm{KH}_{2} \mathrm{PO}_{4} \\
1.5 \mathrm{M} \mathrm{NaCl} \\
30 \mathrm{mM} \mathrm{Na}_{2} \mathrm{PO}_{4} .7 \mathrm{H}_{2} \mathrm{O}\end{array}$ & \\
\hline 10X SDS running buffer & 10X Transfer buffer \\
\hline $\begin{array}{l}30 \mathrm{~g} \text { Tris base } \\
144 \mathrm{~g} \text { Glycine } \\
10 \mathrm{~g} \mathrm{SDS} \\
\mathrm{dH}_{2} \mathrm{O} \text { to } 11\end{array}$ & $\begin{array}{l}30 \mathrm{~g} \text { Tris base } \\
144 \mathrm{~g} \text { Glycine } \\
\mathrm{dH}_{2} \mathrm{O} \text { to } 11\end{array}$ \\
\hline 10X TBS pH to 7.6 & $1 \mathrm{X}$ TBST \\
\hline $\begin{array}{l}24 \mathrm{~g} \text { of Tris Base } \\
88 \mathrm{~g} \text { of } \mathrm{NaCl} \\
\mathrm{dH}_{2} \mathrm{O} \text { to } 1 \mathrm{l}\end{array}$ & 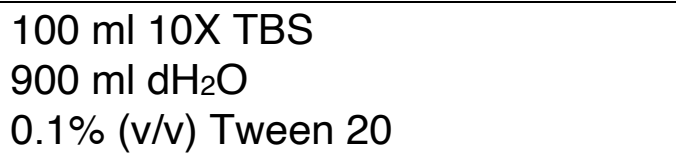 \\
\hline
\end{tabular}

\begin{tabular}{|c|c|c|}
\hline \multicolumn{3}{|l|}{ Primers } \\
\hline Name & Sequence (5' to 3') & Application \\
\hline rc2263f & $\begin{array}{l}\text { CGCGGATCCATCCGGCGAGAGAGTGTCT } \\
\text { TTG }\end{array}$ & \multirow{2}{*}{$\begin{array}{l}\text { Genomic } \\
\text { genomic } \\
\text { construct of } a- \\
\text { PheRS }\end{array}$} \\
\hline rc2263r & CGGGGTACCTATGCCTGGCGATAATCGTG & \\
\hline $\begin{array}{l}\text { Tyr412Cys \& } \\
\text { Phe438Cys-F }\end{array}$ & $\begin{array}{l}\text { TCAAGCCGGCGTACAATCCGTGTACCGAG } \\
\text { CCCAG }\end{array}$ & \multirow{2}{*}{$\begin{array}{l}\text { Construct of } a- \\
\text { PheRSCys } \\
\text { mutation }\end{array}$} \\
\hline $\begin{array}{l}\text { Tyr412Cys \& } \\
\text { Phe438Cys-R }\end{array}$ & CTCCGGCCGACAGACGCCCGAGTTGCCC & \\
\hline $\begin{array}{l}\text { a-PheRS RNAi } \\
11 f\end{array}$ & $\begin{array}{l}\text { TAATACGACTCACTATAGGGAGGCAAGAA } \\
\text { ACGCAAGCTCCTC }\end{array}$ & \multirow[t]{2}{*}{$\begin{array}{l}\text { a-PheRS ds } \\
\text { RNA synthesis }\end{array}$} \\
\hline $\begin{array}{l}\text { a-PheRS RNAi } \\
11 \mathrm{r}\end{array}$ & $\begin{array}{l}\text { TAATACGACTCACTATAGGGAGGGAACTC } \\
\text { CGCCAGATGTGTG }\end{array}$ & \\
\hline $\begin{array}{l}\beta-P h e R S \text { RNAi } \\
\text { 10f }\end{array}$ & $\begin{array}{l}\text { TAATACGACTCACTATAGGGAGGGCCAAT } \\
\text { CATTCGGGAATCA }\end{array}$ & \multirow[t]{2}{*}{$\begin{array}{l}\beta \text {-PheRS ds } \\
\text { RNA synthesis }\end{array}$} \\
\hline $\begin{array}{l}\beta \text {-PheRS RNAi } \\
\text { 10r }\end{array}$ & $\begin{array}{l}\text { TAATACGACTCACTATAGGGAGGAGGCAG } \\
\text { GGACTTCTTAATGT }\end{array}$ & \\
\hline seq r6 & GCTCCCATTCATCAGTTCC & Sequencing \\
\hline seqA r1 & CATTTCCACCGTGAGATCCGTC & Sequencing \\
\hline seqA r2 & AACTCTTGTGGGTGACCGTTTC & Sequencing \\
\hline seqA f1 & GTTCTCGAAGTGAATGTTCTGG & Sequencing \\
\hline
\end{tabular}




\begin{tabular}{|l|l|l|}
\hline seqA f2 & TTTAGCCACCGTCGTCGTTTC & Sequencing \\
\hline seqA r3 & TCCAGCGACGATGACGAATTTG & Sequencing \\
\hline seqA f3 & CAAATGGATTGTGGGACCAGC & Sequencing \\
\hline seqA r4 & GCCCTCCTCCACCATCTTTAG & Sequencing \\
\hline
\end{tabular}

\section{Fly genetics and husbandry}

332 All Drosophila melanogaster fly stocks were kept for long term storage at $18^{\circ} \mathrm{C}$ in glass or

333 plastic vials on standard food with day/night $(12 \mathrm{~h} / 12 \mathrm{~h})$ light cycles. All experiments were

334 performed at $25^{\circ} \mathrm{C}$ unless specifically mentioned. A UAS-GFP element was added in

335 experiments that tested for rescue and involved Gal4 mediated expression of the rescue gene.

336 This construct served to even out the number of UAS sites in each Gal4 expressing cell. Origins

337 of all stocks are noted in Table 1, the Key Resource Table.

\section{DNA cloning and generation of transgenic flies}

340 Sequence information was obtained from Flybase. All mutations and the addition of the Myc-

341 tag to the N-terminus of $\alpha$-PheRS were made by following the procedure of the QuickChange ${ }^{\circledR}$

342 Site-Directed Mutagenesis Kit (Stratagene). The genomic $\alpha$-PheRS rescue construct (Myc:: $\alpha$ -

343 PheRS) codes for the entire coding region and for an additional Myc tag at the N-terminal end.

344 In addition, it contains $\sim 1 \mathrm{~kb}$ of up- and down-stream sequences and it was cloned into the

$345 p w^{+} S N a t t B$ transformation vector (Koch et al., 2009; Lu et al., 2014). The $\alpha-P h e R S$ and $\beta$ -

346 PheRS cDNAs were obtained by RT-PCR from mRNA isolated from 4-8 days old OreR flies

347 (Lu et al., 2014). The Tyr412Cys and Phe438Cys mutations in the $\alpha$-PheRS sequence were

348 created by site directed mutagenesis. Like the wild-type cDNA, they were cloned into the $349 p U A S T a t t B$ transformation vector to generate the pUAS- $\alpha$-PheRS and pUAS- $\alpha$-PheRS ${ }^{\text {Cys }}$.

350 Before injecting these constructs into fly embryos, all plasmids were verified by sequencing 
351 (Microsynth AG, Switzerland). Transgenic flies were generated by applying the $\phi$ C31-based integration system with the stock ( $y$ w att2A[vas- $\phi] ;+;$ attP-86F) (Bischof et al., 2007).

354 Western blotting

355 Protein was extracted from tissues, whole larvae, or flies using lysis buffer. Protein lysates were separated by SDS-PAGE and transferred onto PVDF membranes (Milipore, US). The blocking was performed for $1 \mathrm{~h}$ at room temperature (RT) with non-fat dry milk (5\%) in TBST solution. Blots were probed first with primary antibodies (diluted in blocking buffer) overnight at $4^{\circ} \mathrm{C}$ and then with secondary antibodies (diluted in TBST) $1 \mathrm{~h}$ at RT. The signal of the secondary antibody was detected by using the detect solution mixture (1:1) (ECLTM Prime noted in Table 1, the Key Resource Table.

\section{Immunofluorescent staining and confocal microscopy}

366 Dissections were performed in 1x PBS on ice and tissues were collected within maximum one

367 hour. Fixation with 4\% PFA in PBS-T $0.2 \%$ at RT was done for 30 minutes (wing discs, ovaries). Then the samples were blocked overnight with blocking buffer at $4^{\circ} \mathrm{C}$. Primary antibodies (diluted in blocking buffer) were incubated with the samples for $8 \mathrm{~h}$ at RT. The samples were rinsed 3 times and washed 3 times (20 minutes/wash) with PBST. Secondary antibodies (diluted in PBST) were incubated overnight at $4^{\circ} \mathrm{C}$. The samples were then rinsed 3

372 times and washed 2 times (20 minutes/wash) with PBST. Hoechst $33258(2.5 \mu \mathrm{g} / \mathrm{ml})$ was added

373 in PBST before the last washing step and the samples were mounted with Aqua/Poly Mount 
374 solution (Polysciences Inc., US). Origins and diluted concentrations of all buffers and antibodies are noted in Table 1, the Key Resource Table.

Protein synthesis measurements using the ribopuromycylation method (RPM)

378 For puromycin labeling experiments, tissues were dissected in Schneider's insect medium (Sigma, US) supplement with $10 \%$ fetal calf serum (FCS, Sigma, US) at $25^{\circ} \mathrm{C}$. They were then incubated with Schneider's insect medium containing puromycin $(5 \mu \mathrm{g} / \mathrm{ml}$, Sigma, US) and cycloheximine (CHX, $100 \mu \mathrm{g} / \mathrm{ml}$, Sigma, US) for 2 hours at RT. Then the samples were fixed with $4 \%$ PFA in PBS-T $0.2 \%$ at RT and blocked overnight with blocking buffer at $4^{\circ} \mathrm{C}$. Primary anti-Puromycin antibody (diluted in PBST) was incubated with the samples for $8 \mathrm{~h}$ at RT. The samples were rinsed 3 times and washed 3 times (20 minutes/wash) with PBST. Secondary antibodies (diluted in PBST) were incubated overnight at $4^{\circ} \mathrm{C}$. The samples were then rinsed 3 times and washed 2 times (20 minutes/wash) with PBST. Hoechst $33258(2.5 \mu \mathrm{g} / \mathrm{ml})$ was added in PBST before the last washing step and the samples were mounted with Aqua/Poly Mount solution (Polysciences Inc., US).

\section{In vitro aminoacylation assay}

391 Recombinant $\alpha$-PheRS and $\beta$-PheRS proteins were co-expressed in the $E$. coli strain Rosetta

392 (Novagen) and then purified (Moor et al., 2002). For this, the $\alpha$-PheRS or $\alpha$-PheRS ${ }^{C y s}$ mutant cDNAs were cloned with His tags at the N-terminal end into the pET-28a plasmid expression

394 vector (Novagen). Wild-type $\beta$-PheRS cDNAs were cloned into the pET LIC (2A-T) plasmid 395 (Addgene). Then, His- $\alpha$-PheRS or the His- $\alpha$-PheRS ${ }^{\text {Cys }}$ mutant and $\beta$-PheRS were co-expressed

396 in the E. coli strain Rosetta with isopropylthiogalactoside (IPTG, $1 \mathrm{mM}$ ) induction at $25^{\circ} \mathrm{C}$ for 3976 hours. Proteins were purified with Ni-NTA affinity resin (Qiagen). The aminoacylation assay 
protocol from Jiongming Lu was then followed (Lu et al., 2014) with the modification that the

Whatman filter paper discs were soaked in Phenylalanine solution for 1 hour $(30 \mathrm{mg} / \mathrm{ml}$ in $5 \%$ trichloroacetic acid (TCA)) to reduce the background. This assay was performed at $25^{\circ} \mathrm{C}$ in a $100 \mu \mathrm{l}$ reaction mixture containing $50 \mathrm{mM}$ Tris- $\mathrm{HCl} \mathrm{pH}$ 7.5, $10 \mathrm{mM} \mathrm{MgCl} 2,4 \mathrm{mM}$ ATP, $5 \mathrm{mM}$

$402 \beta$-mercaptoethanol, $100 \mu \mathrm{g} / \mathrm{ml} \mathrm{BSA}, 3 \mathrm{U} / \mathrm{ml}$ E. coli carrier tRNA, $5 \mu \mathrm{M}\left[{ }^{3} \mathrm{H}\right]$-amino acid (L403 Phe) and $1 \mu \mathrm{M}$ tRNA ${ }^{\text {Phe }}$ from brewer's yeast (Sigma, US). In each experiment, a 15- $\mu$ l aliquot was removed at four different incubation time points, spotted on the Phe-treated Whatman filter paper discs and washed three times with ice-cold 5\% TCA and once with ice-cold ethanol. A blank paper disc without spotting and another with spotting the enzyme-free reaction were used

407 for detecting background signals. After filter discs were dried, they were immersed in PPO 408 Toluol (Sigma, US) solution in plastic bottles and the radioactivity was measured by scintillation counting.

\section{Wing disc dissociation and FACS analysis}

412 Wandering larvae derived from 2-4 hours egg collections were dissected in PBS during a

413 maximal time of 30 minutes. Around twenty wing discs were incubated with gentle agitation 414 at $29^{\circ} \mathrm{C}$ for around 2-hours in $500 \mu 110 \times$ Trypsin-EDTA supplemented with $50 \mu 110 \times$ Hank's

415 Balanced Salt Solution (HBSS) (Sigma, US) and $10 \mu \mathrm{l}$ Vybrant DyeCycle Ruby stain 416 (Molecular Probes, US). Dissociated cells from wing discs were directly analyzed by FACS417 Calibur flow cytometer (Becton Dickinson, US).

419 with a staining solution containing $1 \mathrm{mg} / \mathrm{ml}$ propidium iodide, $0.1 \%$ Triton and $10 \mathrm{mg} / \mathrm{ml} \mathrm{RNase}$

420 A. The cells were then subjected to FACS-Calibur cytometry and data were analyzed with the

421 FlowJo software. 


\section{Drosophila cell culture and RNAi treatment}

424 Drosophila Kc cells were incubated at $25^{\circ} \mathrm{C}$ in Schneider's Drosophila medium supplemented 425 with $10 \%$ heat-inactivated fetal calf serum (FCS) and $50 \mu \mathrm{g} / \mathrm{ml}$ Penicillin/Streptomycin. To 426 induce RNAi knockdown in Drosophila cells, dsRNA treatment was performed (Clemens et 427 al., 2000). dsRNAs around 500bp in length were generated with the RNAMaxx ${ }^{\mathrm{TM}}$ High Yield 428 Transcription Kit (Agilent, US). Cells were diluted to a concentration of $10^{6}$ cells $/ \mathrm{ml}$ in serum429 free medium, and dsRNA was added directly to the medium at a concentration of $15 \mu \mathrm{g} / \mathrm{ml}$.

430 The cells were incubated for 1 hour followed by addition of medium containing FCS. Then the 431 cells were kept in the incubator and were harvested at different time points 1-5 days after 432 dsRNA treatment.

\section{Clonal assay and twin spot data analysis}

435 For twin spot tests, we used the Mosaic Analysis with a Repressible Cell Marker (MARCM) 436 system. Twin spots were generated with the progenitor genotype $h s-f l p$; tub-Gal4/UAS- $\beta$ PheRS ; FRT82B, ubiGFP, UAS- $\alpha-P h e R S^{(C y s)} / F R T 82 B$ Tub-Gal80. In twin spots, the internal control clone was GFP-minus and the twin sister clone produced a red signal by the antibody against the overexpressed protein. We induced the $h s-F L P, F R T 82 B$ system at $37^{\circ} \mathrm{C}$ for $1 \mathrm{~h}$ on

440 the third day post-eclosure and dissected the animals 3 days post-induction. Confocal imaging 441 detected non-green clones (without ubiGFP) and red clones (stained with Myc antibody-red) 442 (Fig 5A).

In twin spots, cell numbers per clone were counted and the numbers of cell divisions

444 per clone were calculated as $\log _{2}$ (cell numbers per clone). This represents the logarithm of the 445 cell numbers per clone to the base 2 . The increase of cell proliferation (\%) was analyzed by 
comparing the number of cell divisions of the clone pairs in the same twin spot. The clone sizes

447 were measured by FIJI software and the increase of clone size was analyzed by comparing the

448 clone size in the same twin spot.

\section{Image acquisition and processing}

451 Imaging was carried out with a Leica SP8 confocal laser scanning microscope equipped with a $405 \mathrm{~nm}$ diode laser, a 458, 476, 488, 496 and $514 \mathrm{~nm}$ Argon laser, a $561 \mathrm{~nm}$ diode pumped solid state laser and a $633 \mathrm{~nm}$ HeNe laser. Images were obtained with 20x dry and 63x oilimmersion objectives and 1024x1024 pixel format. Images were acquired using LAS X software. The images of the entire gut were obtained by imaging at the standard size and then merging maximal projections of Z-stacks with the Tiles Scan tool. Fluorescent intensity was determined from FIJI software.

\section{Quantification and statistical analysis}

460 For quantifications of all experiments, $n$ represents the number of independent biological 461 samples analyzed (the number of wing discs, the number of twin spots), error bars represent 462 standard deviation (SD). Statistical significance was determined using the t-test or ANOVA as

463 noted in the figure legends. They were expressed as P values. $(*)$ denotes $\mathrm{p}<0.05,(* *)$ denotes $464 \mathrm{p}<0.01,(* * *)$ denotes $\mathrm{p}<0.001,(* * * *)$ denotes $\mathrm{p}<0.0001$. (ns) denotes values whose difference was not significant. 


\section{Acknowledgements}

469 We thank Hugo Stocker, Albena Jordanova, Erik Storkebaum, and the Bloomington Stock

470 Center for fly stocks. We are also grateful to Mark Safro for suggesting mutations that disrupt

471 the phenylalanine binding site of $\alpha$-PheRS. We further thank Dominique Brunssen and

472 Jonathan Huot for their valuable advice on the aminoacylation assay. This work was

473 supported by the Novartis Foundation for medical-biological Research (\#18A050), the Swiss

474 National Fund (project grant 31003A_173188), and the University/Canton of Bern. 
476 Adam, I., Dewi, D.L., Mooiweer, J., Sadik, A., Mohapatra, S.R., Berdel, B., Keil, M., Sonner, J.K., Thedieck, K., Rose, A.J., Platten, M., Heiland, I., Trump, S., Opitz, C.A., 2018. Upregulation of tryptophanyl-tRNA synthethase adapts human cancer cells to nutritional stress caused by tryptophan degradation. Oncoimmunology 7, e1486353.

Antonellis, A., Oprescu, S.N., Griffin, L.B., Heider, A., Amalfitano, A., Innis, J.W., 2018. Compound heterozygosity for loss-of-function FARSB variants in a patient with classic features of recessive aminoacyl-tRNA synthetase-related disease. Human mutation 39, 834840.

Barker, N., Ridgway, R.A., van Es, J.H., van de Wetering, M., Begthel, H., van den Born, M., 485 Danenberg, E., Clarke, A.R., Sansom, O.J., Clevers, H., 2009. Crypt stem cells as the cellsof-origin of intestinal cancer. Nature 457, 608-611.

487 Bischof, J., Maeda, R.K., Hediger, M., Karch, F., Basler, K., 2007. An optimized transgenesis 488 system for Drosophila using germ-line-specific phiC31 integrases. Proceedings of the 489 National Academy of Sciences of the United States of America 104, 3312-3317.

490 Bonfils, G., Jaquenoud, M., Bontron, S., Ostrowicz, C., Ungermann, C., De Virgilio, C., 491 2012a. Leucyl-tRNA synthetase controls TORC1 via the EGO complex. Molecular cell 46, $492 \quad 105-110$.

493 Bonfils, G., Jaquenoud, M., Bontron, S.v., Ostrowicz, C., Ungermann, C., De Virgilio, C., 494 2012b. Leucyl-tRNA synthetase controls TORC1 via the EGO complex. Molecular cell 46, $495 \quad 105-110$.

496 Casas-Tinto, S., Lolo, F.N., Moreno, E., 2015. Active JNK-dependent secretion of 497 Drosophila Tyrosyl-tRNA synthetase by loser cells recruits haemocytes during cell 498 competition. Nature communications 6, 10022.

499 Chen, J., Larochelle, S., Li, X., Suter, B., 2003a. Xpd/Ercc2 regulates CAK activity and 500 mitotic progression. Nature 424, 228-232.

501 Chen, J., Larochelle, S.p., Li, X., Suter, B., 2003b. Xpd/Ercc2 regulates CAK activity and 502 mitotic progression. Nature 424, 228-232.

503 Clemens, J.C., Worby, C.A., Simonson-Leff, N., Muda, M., Maehama, T., Hemmings, B.A., 504 Dixon, J.E., 2000. Use of double-stranded RNA interference in Drosophila cell lines to 505 dissect signal transduction pathways. Proceedings of the National Academy of Sciences 97, 506 6499-6503.

507 Deliu, L.P., Ghosh, A., Grewal, S.S., 2017. Investigation of protein synthesis in Drosophila 508 larvae using puromycin labelling. Biology open 6, 1229-1234. 
509 Dolde, C., Lu, J., Suter, B., 2014. Cross Talk between Cellular Regulatory Networks

510 Mediated by Shared Proteins. Advances in Biology 2014, 12.

511 Finarov, I., Moor, N., Kessler, N., Klipcan, L., Safro, M.G., 2010. Structure of human

512 cytosolic phenylalanyl-tRNA synthetase: evidence for kingdom-specific design of the active

513 sites and tRNA binding patterns. Structure 18, 343-353.

514 Gomard-Mennesson, E., Fabien, N., Cordier, J.F., Ninet, J., Tebib, J., Rousset, H., 2007.

515 Clinical significance of anti-histidyl-tRNA synthetase (Jo1) autoantibodies. Annals of the

516 New York Academy of Sciences 1109, 414-420.

517 Greenberg, Y., King, M., Kiosses, W.B., Ewalt, K., Yang, X., Schimmel, P., Reader, J.S.,

518 Tzima, E., 2008. The novel fragment of tyrosyl tRNA synthetase, mini-TyrRS, is secreted to 519 induce an angiogenic response in endothelial cells. FASEB journal : official publication of

520 the Federation of American Societies for Experimental Biology 22, 1597-1605.

521 Guo, M., Schimmel, P., 2013. Essential nontranslational functions of tRNA synthetases.

522 Nature chemical biology 9, 145-153.

523 Guo, M., Yang, X.L., Schimmel, P., 2010. New functions of aminoacyl-tRNA synthetases

524 beyond translation. Nature reviews. Molecular cell biology 11, 668-674.

525 Han, J.M., Jeong, S.J., Park, M.C., Kim, G., Kwon, N.H., Kim, H.K., Ha, S.H., Ryu, S.H., 526 Kim, S., 2012a. Leucyl-tRNA synthetase is an intracellular leucine sensor for the mTORC1527 signaling pathway. Cell 149, 410-424.

528 Han, J.M., Jeong, S.J., Park, M.C., Kim, G., Kwon, N.H., Kim, H.K., Ha, S.H., Ryu, S.H., 529 Kim, S., 2012b. Leucyl-tRNA synthetase is an intracellular leucine sensor for the mTORC1530 signaling pathway. Cell 149, 410-424.

531 Kim, D.-H., Sarbassov, D.D., Ali, S.M., King, J.E., Latek, R.R., Erdjument-Bromage, H., 532 Tempst, P., Sabatini, D.M., 2002. mTOR interacts with raptor to form a nutrient-sensitive 533 complex that signals to the cell growth machinery. Cell 110, 163-175.

534 Kim, E., Goraksha-Hicks, P., Li, L., Neufeld, T.P., Guan, K.-L., 2008. Regulation of TORC1 535 by Rag GTPases in nutrient response. Nature cell biology 10, 935-945.

536 Ko, Y.G., Kang, Y.S., Kim, E.K., Park, S.G., Kim, S., 2000. Nucleolar localization of human 537 methionyl-tRNA synthetase and its role in ribosomal RNA synthesis. The Journal of cell 538 biology 149, 567-574.

539 Ko, Y.G., Kim, E.Y., Kim, T., Park, H., Park, H.S., Choi, E.J., Kim, S., 2001. Glutamine540 dependent antiapoptotic interaction of human glutaminyl-tRNA synthetase with apoptosis 541 signal-regulating kinase 1 . The Journal of biological chemistry 276, 6030-6036. 
542 Koch, R., Ledermann, R., Urwyler, O., Heller, M., Suter, B., 2009. Systematic functional 543 analysis of Bicaudal-D serine phosphorylation and intragenic suppression of a female sterile 544 allele of BicD. PloS one 4, e4552.

545 Laplante, M., Sabatini, D.M., 2012. mTOR signaling in growth control and disease. Cell 149, 546 274-293.

547 Lee, S.W., Cho, B.H., Park, S.G., Kim, S., 2004. Aminoacyl-tRNA synthetase complexes: 548 beyond translation. Journal of cell science 117, 3725-3734.

549 Ling, J., Yadavalli, S.S., Ibba, M., 2007. Phenylalanyl-tRNA synthetase editing defects result 550 in efficient mistranslation of phenylalanine codons as tyrosine. RNA 13, 1881-1886. synthetase causes protein mistranslation and affects cellular physiology and development.

553 Nature communications 5, 5650.

554 Lu, J., Marygold, S.J., Gharib, W.H., Suter, B., 2015. The aminoacyl-tRNA synthetases of 555 Drosophila melanogaster. Fly 9, 53-61.

556 Moor, N., Linshiz, G., Safro, M., 2002. Cloning and expression of human phenylalanyl-tRNA 557 synthetase in Escherichia coli: comparative study of purified recombinant enzymes. Protein 558 expression and purification 24, 260-267.

559 Mosyak, L., Reshetnikova, L., Goldgur, Y., Delarue, M., Safro, M.G., 1995. Structure of 560 phenylalanyl-tRNA synthetase from Thermus thermophilus. Nature structural biology 2, 537561547.

562 Nathanson, L., Deutscher, M.P., 2000. Active aminoacyl-tRNA synthetases are present in 563 nuclei as a high molecular weight multienzyme complex. The Journal of biological chemistry $564275,31559-31562$.

565 Otani, A., Slike, B.M., Dorrell, M.I., Hood, J., Kinder, K., Ewalt, K.L., Cheresh, D., 566 Schimmel, P., Friedlander, M., 2002. A fragment of human TrpRS as a potent antagonist of 567 ocular angiogenesis. Proceedings of the National Academy of Sciences of the United States 568 of America 99, 178-183.

569 Pang, Y.L., Poruri, K., Martinis, S.A., 2014. tRNA synthetase: tRNA aminoacylation and 570 beyond. Wiley interdisciplinary reviews. RNA 5, 461-480.

571 Park, S.J., Yoon, B.H., Kim, S.K., Kim, S.Y., 2019. GENT2: an updated gene expression 572 database for normal and tumor tissues. BMC medical genomics 12, 101.

573 Rodova, M., Ankilova, V., Safro, M.G., 1999. Human phenylalanyl-tRNA synthetase: 574 cloning, characterization of the deduced amino acid sequences in terms of the structural 575 domains and coordinately regulated expression of the alpha and beta subunits in chronic 
myeloid leukemia cells. Biochemical and biophysical research communications 255, 765773.

578 Roy, H., Ibba, M., 2006. Phenylalanyl-tRNA synthetase contains a dispensable RNA-binding 579 domain that contributes to the editing of noncognate aminoacyl-tRNA. Biochemistry 45, 580 9156-9162.

581 Sancak, Y., Peterson, T.R., Shaul, Y.D., Lindquist, R.A., Thoreen, C.C., Bar-Peled, L., 582 Sabatini, D.M., 2008. The Rag GTPases bind raptor and mediate amino acid signaling to 583 mTORC1. Science 320, 1496-1501.

584 Schimmel, P.R., Soll, D., 1979. Aminoacyl-tRNA synthetases: general features and 585 recognition of transfer RNAs. Annual review of biochemistry 48, 601-648.

586 Sen, S., Zhou, H., Ripmaster, T., Hittelman, W.N., Schimmel, P., White, R.A., 1997.

587 Expression of a gene encoding a tRNA synthetase-like protein is enhanced in tumorigenic

588 human myeloid leukemia cells and is cell cycle stage- and differentiation-dependent.

589 Proceedings of the National Academy of Sciences of the United States of America 94, 61645906169.

591 Smirnova, E.V., Lakunina, V.A., Tarassov, I., Krasheninnikov, I.A., Kamenski, P.A., 2012. 592 Noncanonical functions of aminoacyl-tRNA synthetases. Biochemistry. Biokhimiia 77, 1559325.

594 Texada, M.J., Koyama, T., Rewitz, K., 2020. Regulation of Body Size and Growth Control. 595 Genetics 216, 269-313.

596 Tzima, E., Reader, J.S., Irani-Tehrani, M., Ewalt, K.L., Schwartz, M.A., Schimmel, P., 2005. 597 VE-cadherin links tRNA synthetase cytokine to anti-angiogenic function. The Journal of 598 biological chemistry 280, 2405-2408.

599 Wu, J.S., Luo, L., 2006. A protocol for mosaic analysis with a repressible cell marker 600 (MARCM) in Drosophila. Nature protocols 1, 2583-2589.

601 Wullschleger, S., Loewith, R., Hall, M.N., 2006. TOR signaling in growth and metabolism. 602 Cell 124, 471-484.

603 Xu, Z., Lo, W.S., Beck, D.B., Schuch, L.A., Olahova, M., Kopajtich, R., Chong, Y.E., 604 Alston, C.L., Seidl, E., Zhai, L., Lau, C.F., Timchak, D., LeDuc, C.A., Borczuk, A.C., Teich, 605 A.F., Juusola, J., Sofeso, C., Muller, C., Pierre, G., Hilliard, T., Turnpenny, P.D., Wagner, 606 M., Kappler, M., Brasch, F., Bouffard, J.P., Nangle, L.A., Yang, X.L., Zhang, M., Taylor, 607 R.W., Prokisch, H., Griese, M., Chung, W.K., Schimmel, P., 2018. Bi-allelic Mutations in 608 Phe-tRNA Synthetase Associated with a Multi-system Pulmonary Disease Support Non609 translational Function. American journal of human genetics 103, 100-114. 
610 Yannay-Cohen, N., Carmi-Levy, I., Kay, G., Yang, C.M., Han, J.M., Kemeny, D.M., Kim,

611 S., Nechushtan, H., Razin, E., 2009. LysRS serves as a key signaling molecule in the immune

612 response by regulating gene expression. Molecular cell 34, 603-611.

613 Zhou, J.J., Wang, F., Xu, Z., Lo, W.S., Lau, C.F., Chiang, K.P., Nangle, L.A., Ashlock,

614 M.A., Mendlein, J.D., Yang, X.L., Zhang, M., Schimmel, P., 2014. Secreted histidyl-tRNA

615 synthetase splice variants elaborate major epitopes for autoantibodies in inflammatory

616 myositis. The Journal of biological chemistry 289, 19269-19275.

618 Figure legends:

Fig 1: PheRS knockdown reduces growth.

621 (A) PheRS knockdown in eye discs results in smaller eyes. eyeless-Gal4 was used to drive the

622 knockdown of the $\alpha$ and $\beta$-subunits ( $\alpha$-sub and $\beta$-sub). Control (ctl) is the driver alone. RNAi

623 lines were obtained from VDRC. Scale bar represents $250 \mu \mathrm{m}$. (B) PheRS knockdown in the

624 larval fat body results in smaller pupae. ppl-Gal4 was used to drive the knockdown. The same

625 RNAi lines were used as in (A). Scale bar represents $500 \mu \mathrm{m}$. (C) PheRS knockdown in Kc

626 cells downregulates cell proliferation. Knockdown was performed by adding dsRNA to the cell

627 medium. Cell numbers were determined during the days following the dsRNA treatment. The

628 result represents two independent experiments. The negative control was GFP RNAi while the

629 positive control was $x p d$ RNAi. (D) $\beta$-PheRS knockdown in Kc cells reduces the frequency of

630 mitotic cells. The mitotic index was determined based on the frequency of the phospho-Histone

$631 \mathrm{H} 3$ positive cells. Over 10,000 cells were counted for each treatment $(\mathrm{P}<0.001)$. (E) $\beta$-PheRS

632 knockdown in Kc cells decreases cell size. The forward scatter (FSC) was used to determine

633 cell size. Raptor RNAi is a positive control, and $\beta$-PheRS knockdown showed similar cell size.

635 Fig 2: PheRS does not act as an amino acid sensor for the TORC1 complex. (A) $\beta$-PheRS

636 knockdown cannot block the TORC1 complex from sensing the availability of amino acids. 
637 Phospho-S6K was used as a readout of TORC1 signaling. Starvation (-) was performed by 638 depriving cells of amino acids for 30 mins, and stimulation $(+)$ was performed by adding back

639 amino acids for 30 mins after starvation. Control is a mock RNAi, Rag $A$ RNAi is known to 640 block the sensing of amino acids. Phospho-S6K levels were quantified relative to the Actin 641 levels in the same extract. (B) $\beta$-PheRS knockdown did not block the TORC1 complex from 642 sensing the availability of L-Phe. The same experiment as in (A) was performed but using L643 Phe and L-Glu for stimulation. L-Glu was reported to be necessary for amino acid transport 644 (Nicklin et al., 2009). Levels of phospho-S6K were quantified relative to the Actin levels in 645 the same extract.

647 Figure 3: Elevated $\alpha-P h e R S$ promotes the appearance of mitotic cells without $\beta$-PheRS and without stimulating translation.

649 (A-C ", ,D) en-Gal4/+;UAS-GFP/UAS- $\alpha-P h e R S^{(C y s)}$ was used to drive transgene expression in 650 order to elevate levels of $\alpha$-PheRS or $\alpha$-PheRS ${ }^{\text {Cys }}$ specifically in the posterior compartment of 651 developing wing discs. (A", A"') Upon staining with the anti- $\alpha$-PheRS antibody, the average pixel intensity was 2-fold higher in the posterior compartment compared to the anterior one (n=5). (B", B',') Mitotic cells were visualized with anti-phospho-Histone H3 (PH3) antibodies (A: anterior compartment; P: posterior compartment). $\mathrm{n}=10,{ }^{*} \mathrm{p}<0.05,{ }^{* *} \mathrm{p}<0.01$ in t-test. (C”) The increase of $\alpha$-PheRS or $\alpha$-PheRS ${ }^{\text {Cys }}$ levels did not affect the levels of $\beta$-PheRS. (E-F”, G)

656 Protein synthesis did not increase upon overexpression of $\alpha$-PheRS or $\alpha$-PheRS and $\beta$-PheRS 657 together. dMyc was used as a positive control (en-Gal4/UAS-Myc::MYC;UAS-GFP/+). en658 Gal4 was used to drive the overexpression of the transgenes in the posterior compartment of 659 the wing discs. Protein synthesis was measured by the mean intensity of the puromycin (PMY) 660 signal labeling the nascent polypeptides. $\mathrm{n}=15, * * * * \mathrm{p}<0.0001$, ns: not significant. 
662 Figure 4: The $\alpha-P h e R S^{C y s}$ mutant does not support aminoacylation in vitro. (A) The

663 aminoacylation assay was performed with the mixture of the recombinant protein ( $\alpha-$ PheRS or $664 \alpha-$ PheRS $^{\text {Cys }}$ and $\beta$-PheRS) simultaneously expressed in E. coli. tRNA ${ }^{\text {Phe }}$ from yeast was aminoacylated with $\left[{ }^{3} \mathrm{H}\right]$ phenylalanine. The $\left[{ }^{3} \mathrm{H}\right]$ phenylalanine decays were counted in a scintillation counter. $\mathrm{CPM}=$ counts per minute. In this assay, wild type $\alpha-\mathrm{PheRS}+\beta$-PheRS

667 subunits together gave rise to CPM measurements between 38,000 and over 60,000 at $30 \mathrm{~min}$. whereas $\alpha-$ PheRS ${ }^{\text {Cys }}+\beta$-PheRS produced $350-820$ CPMs, and $\alpha-P h e R S$ or $\alpha-P h e R S^{\text {Cys }}$ alone between 26 and 372 CPMs. (n=3) (B) Soluble recombinant proteins were affinity purified, eluted, and visualized by Coomassie staining, the protein amounts for each reaction were normalized by a BSA gradient.

Figure 5: Aminoacylation-dead $\alpha$-PheRS levels promote follicle cell growth and proliferation.

675 Clonal twin spot analysis of the effect of overexpression of the PheRS subunits in follicle cells 676 by the MARCM technique (hs-flp; tub-Gal4/UAS- $\beta$-PheRS; FRT82B, ubiGFP, UAS- $\alpha$ 677 PheRS $S^{(C y s)} / F R T 82 B$ Tub-Gal80). Upon inducing mitotic recombination by a heat-shock $\left(37^{\circ} \mathrm{C}\right.$ 678 for 40 minutes), a recombining follicle cell will divide and give rise to two proliferating clones. 679 (A) One clone (red) overexpresses $\alpha$-PheRS and also more GFP and its twin clone (GFP-) does 680 not and expresses normal levels (internal control, outlined with yellow line). Note that for the 681 presentation (but not for the quantification) a Myc-tagged $\alpha$-PheRS was expressed to obtain a 682 very clear picture. (B,C,D) Three days after inducing the recombination, cell numbers and 683 clone sizes were determined and the average number of cell divisions and cell sizes were 
684 calculated for each clone and compared to its twin spot. (\%). $n=30,{ }^{* *} \mathrm{p}<0.01,{ }^{* * *} \mathrm{p}<0.001$, $685 * * * * \mathrm{p}<0.0001$ in ANOVA test.

686 
bioRxiv preprint doi: https://doi.org/10.1101/2020 10.29.360420; this version posted October 29, 2020. The copyright holder for this preprint (which was not certified by peer review) is the author/funder, who has granted bioRxiv a license to display the preprint in perpetuity. It is made available under aCC-BY-NC-ND 4.0 International license.

\section{Figures}




\section{Figure 1}
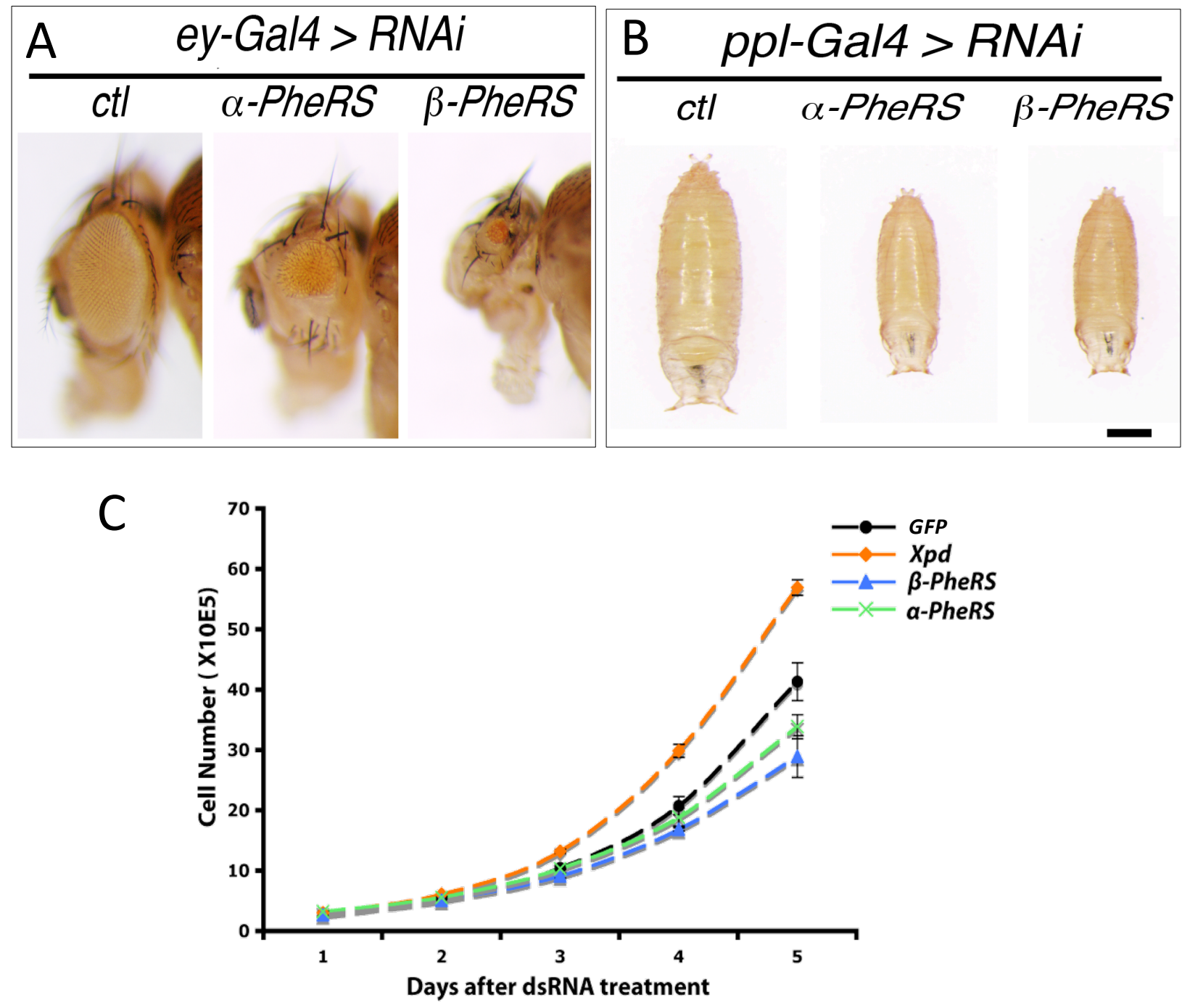

D

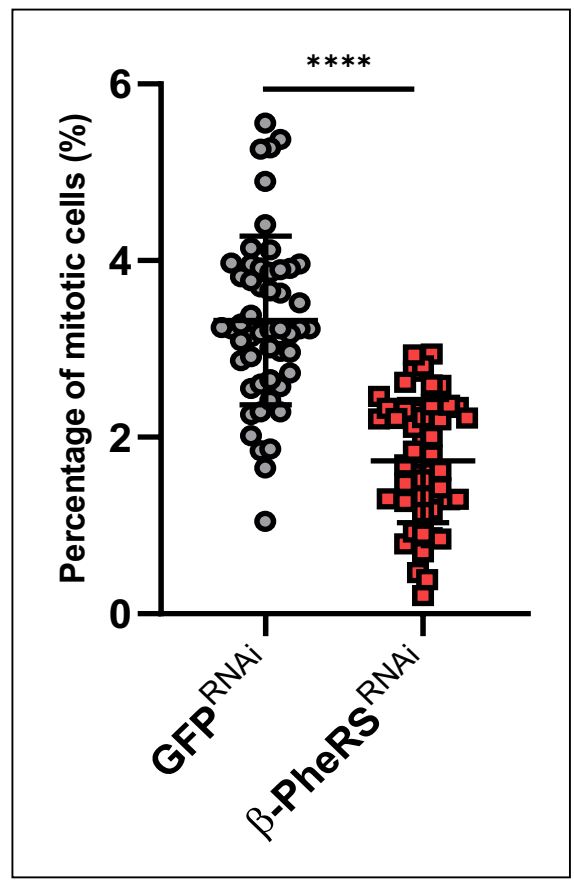

$\mathrm{E}$

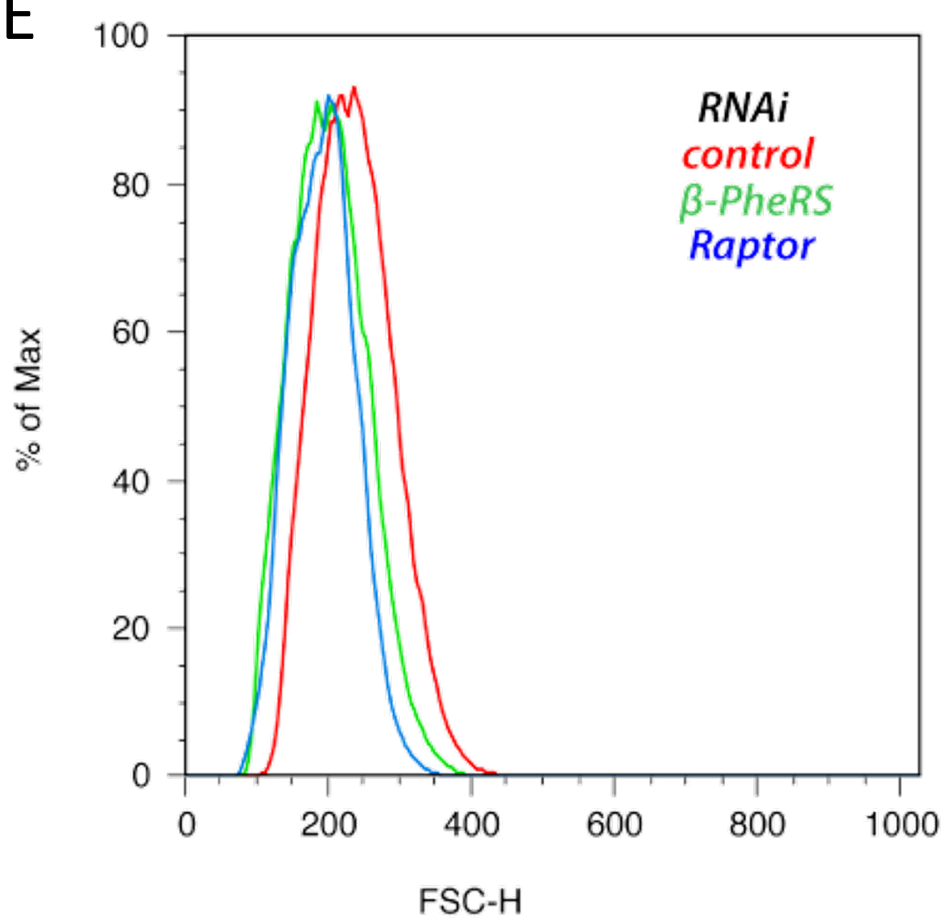


bioRxiv preprint doi: https://doi.org/10.1101/2020.10.29.360420; this version posted October 29, 2020. The copyright holder for this preprint (which was not certified by peer review) is the author/funder, who has granted bioRxiv a license to display the preprint in perpetuity. It is made available under aCC-BY-NC-ND 4.0 International license.

\section{Figure 2}

A

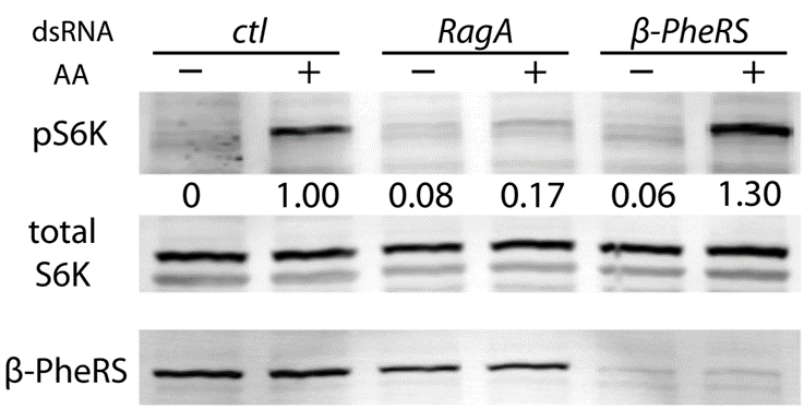

Actin
B

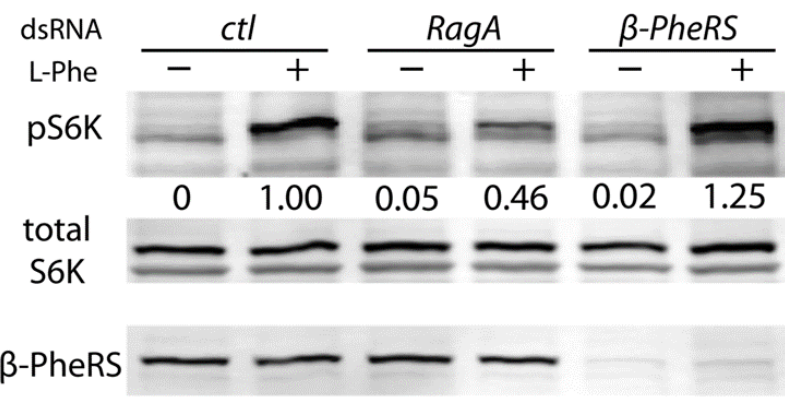

Actin 
Figure 3
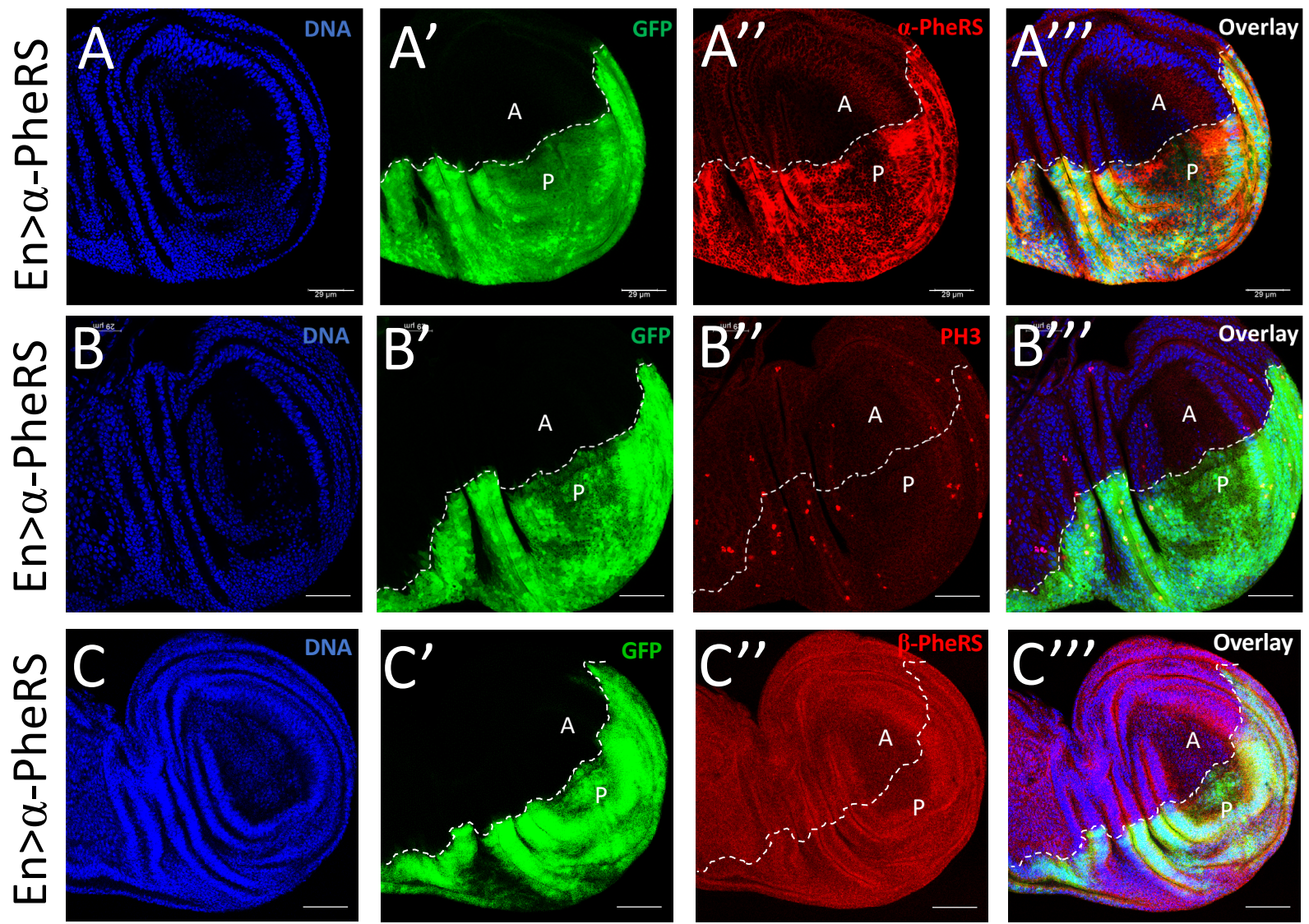

D
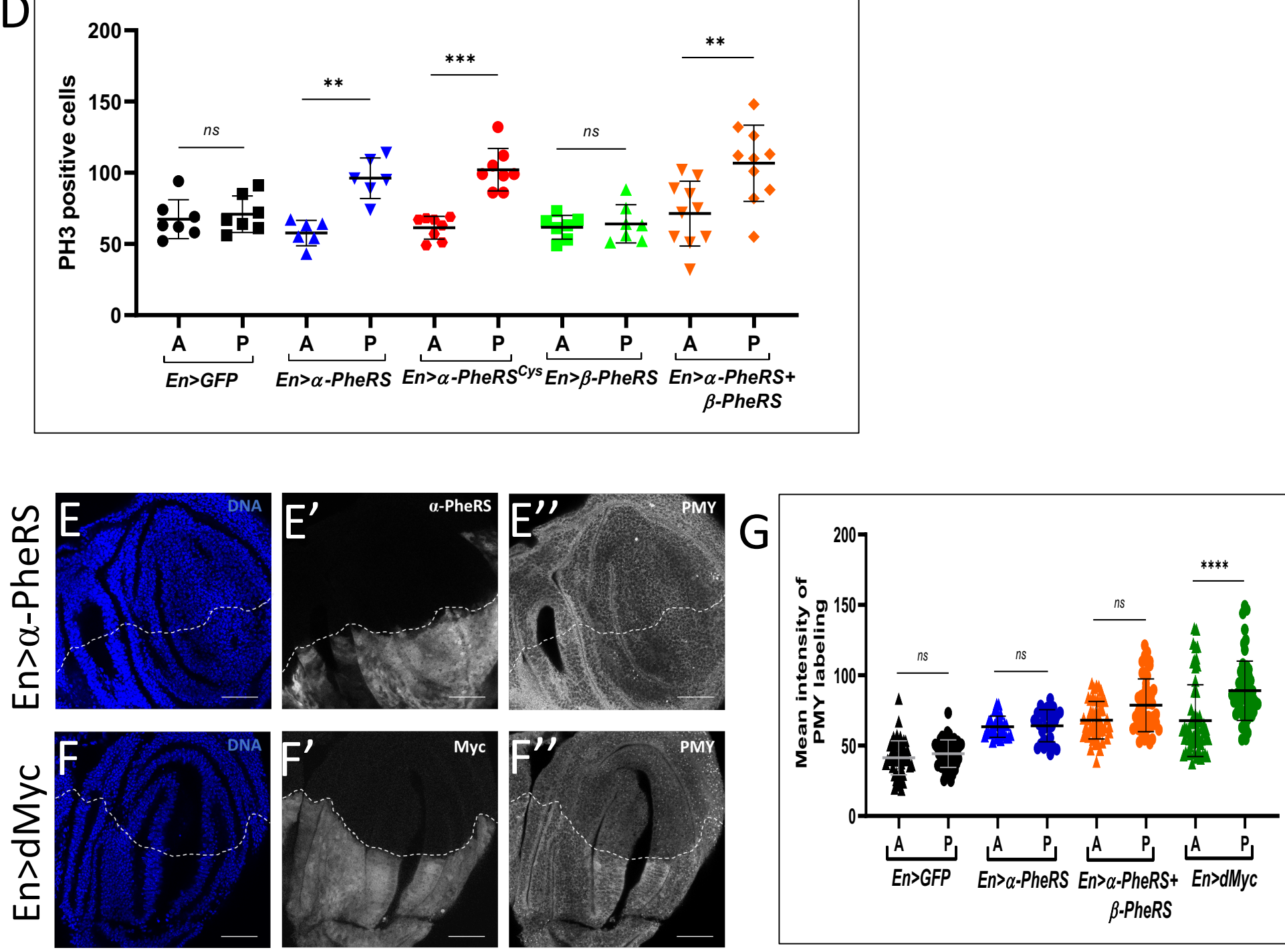

$\beta$-PheRS 


\section{Figure 4}

A

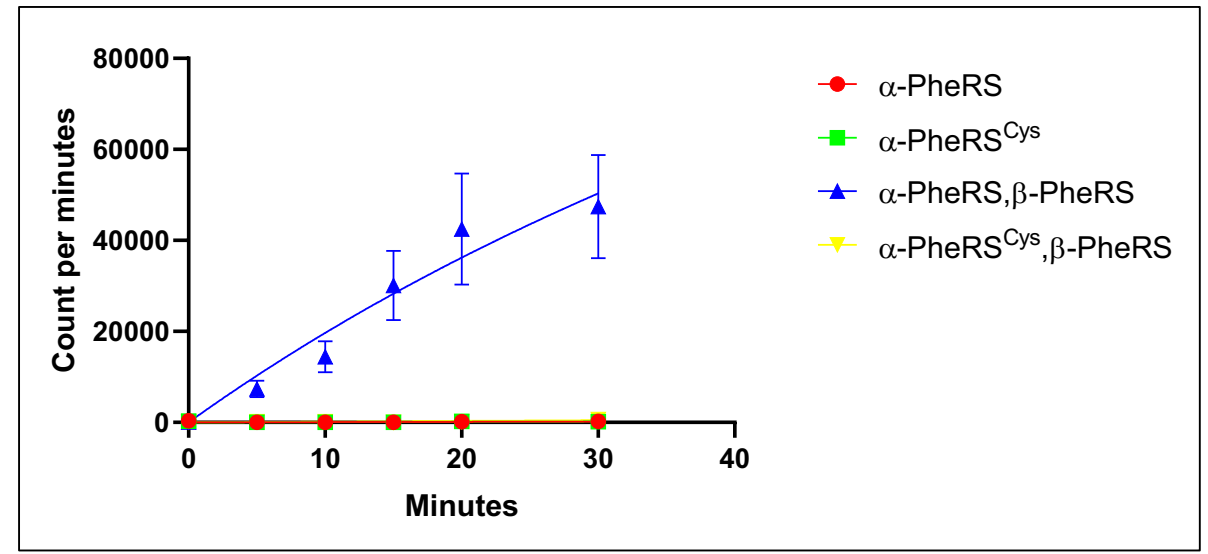

B

\section{Eluate}




Figure 5

A



C

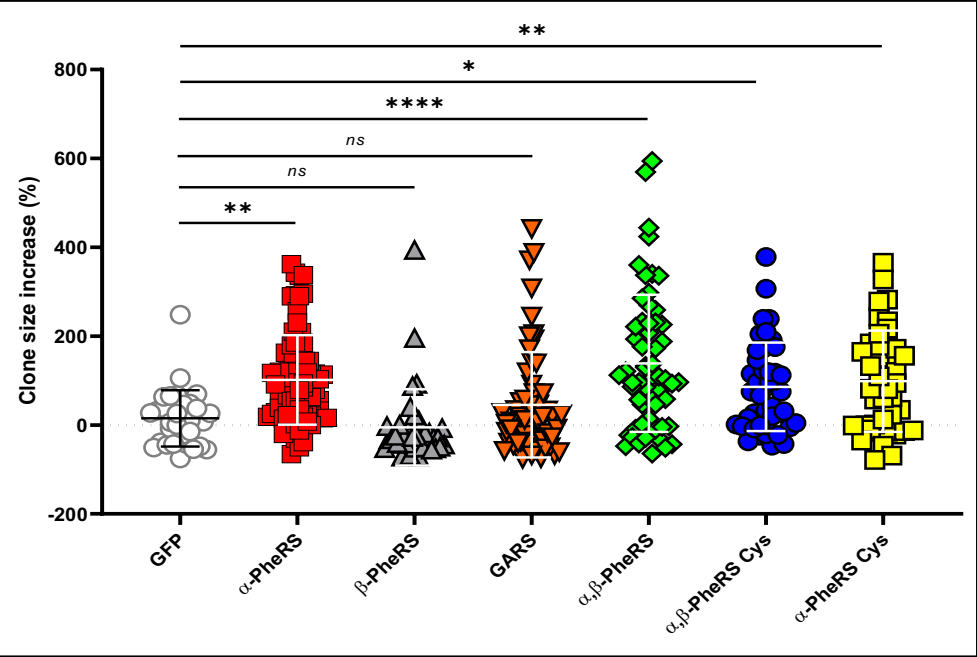

B



D

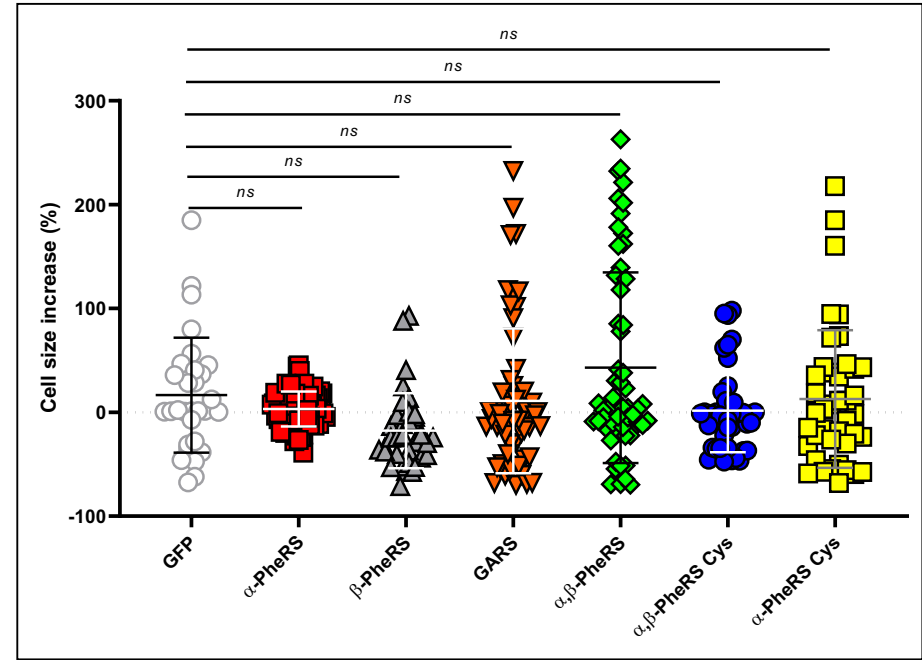

